\title{
Guidelines to Identification and Management of Plant Disease Problems: Part I. Eliminating Insect Damage and Abiotic Disorders ${ }^{1}$
}

\author{
Monica Elliott, Ken Pernezny, Aaron Palmateer, Nikol Havranek ${ }^{2}$
}

\section{Introduction}

Beginning master gardeners can be intimidated by the daunting task of correctly diagnosing the cause of a client's plant health problem. However, with experience and the development of a systematic approach to diagnosis, master gardeners will become confident and successful plant problem detectives.

Plant health problems result from: 1) plant pathogens causing diseases; 2) insects damaging the plant; or 3) environmental factors, often referred to as abiotic disorders. Unfortunately, the symptoms for these health problems are often very similar. A good approach to identification of plant disease is to begin by deductively eliminating insect damage and abiotic disorders as possible alternative causes.

\section{Insect Damage}

One of the reasons to consider insects early in the identification process is the relative ease with which they can be found. Many insects, such as caterpillars and beetles, are fairly large and easy to spot. Even smaller insects like scales (Fig. 1) and related parasites such as mites can be readily seen with a 10x power hand lens. Insect damage is also conspicuous, often consisting of holes in leaves or fruit, leaves with a ragged appearance due to insects chewing along leaf margins, or deformed leaves (Fig. 2).

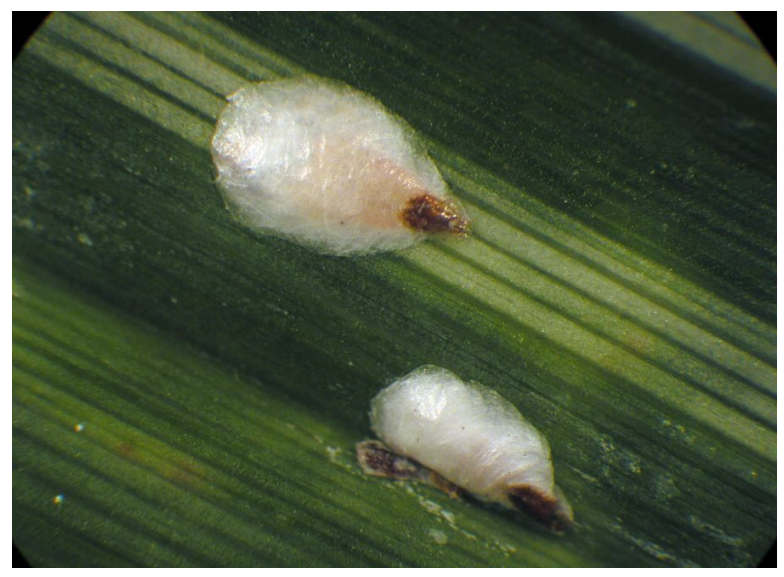

Figure 1. Oleander Scale.

Signs that insects are or have been present include frass --the dark colored droppings they leave

1. This document is PP248, one of a series of the Plant Pathology Department, Florida Cooperative Extension Service, Institute of Food and Agricultural Sciences, University of Florida. Original publication date February, 2008. Visit the EDIS Web Site at http://edis.ifas.ufl.edu.

2. Monica Elliott, professor, Department of Plant Pathology; Fort Lauderdale REC--Ft. Lauderdale, FL; Ken Pernezny, professor, Department of Plant Pathology, Everglades Research and Education Center (REC)--Belle Glade, FL; Aaron Palmateer, assistant professor, Plant Diagnostic Clinic, Tropical REC--Homestead, FL; Nikol Havranek, biological scientist, Everglades REC--Belle Glade, FL; Florida Cooperative Extension Service, Institute of Food and Agricultural Sciences, University of Florida, Gainesville FL 32611.

The Institute of Food and Agricultural Sciences (IFAS) is an Equal Opportunity Institution authorized to provide research, educational information and other services only to individuals and institutions that function with non-discrimination with respect to race, creed, color, religion, age, disability, sex, sexual orientation, marital status, national origin, political opinions or affiliations. U.S. Department of Agriculture, Cooperative Extension Service, University of Florida, IFAS, Florida A. \& M. University Cooperative Extension Program, and Boards of County Commissioners Cooperating. Larry Arrington, Dean 


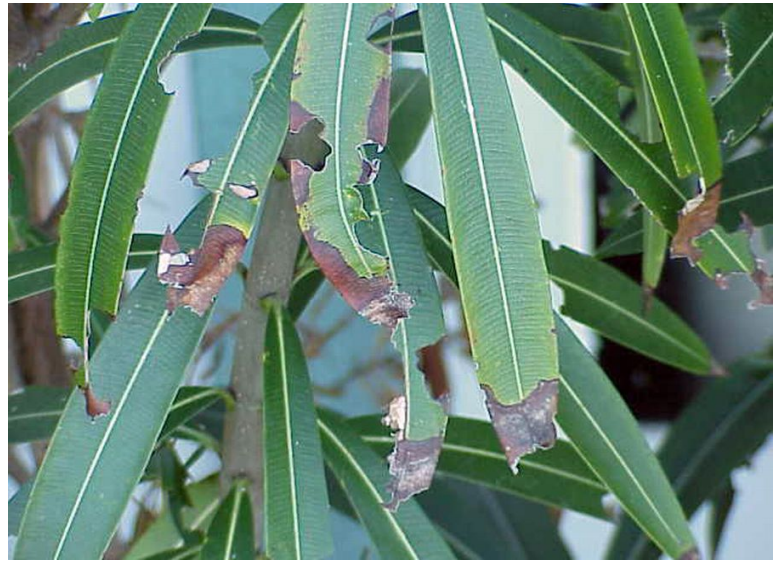

Figure 2. Caterpillar damage.

behind--and sooty mold, associated with sucking insects. Sooty mold is the black superficial growth of a fungus on the honeydew or other material excreted by sucking insects, such as aphids or mealy bugs (Figure 3). The fungus growing on the excretion is not harmful to the plant. When sooty mold is found, the Master Gardener should examine the plant more closely for the presence of insects such as aphids, using a hand lens if needed.

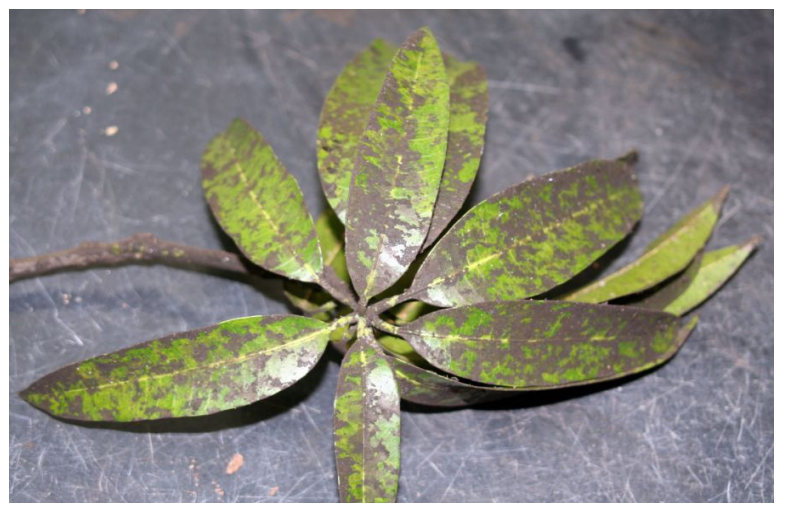

Figure 3. Sooty mold.

Every effort should be made to observe definitive evidence of insect involvement with the plant health problem. If a thorough search consistently yields negative results, then the next step in the process of elimination is to consider an "abiotic" cause for the plant health problem.

\section{Abiotic Disorders}

In Part II of this series on plant disease problems, we will describe in detail the steps to follow in searching for plant pathogens (e.g., fungi, bacteria, viruses) as the causes of plant disease. However, because confirmation of a plant disease can be time consuming and may require sending the sample to a plant diagnostic clinic, eliminating abiotic disorders (usually environmental factors) should be done before searching for a pathogen. Because most plant pathogens require specific environmental conditions in order for a disease to develop, information collected to determine whether there is an abiotic disorder will also be useful for making a disease diagnosis. Moreover, some plants are more likely to suffer from abiotic disorders rather than plant diseases, so taking abiotic causes into consideration first may make the identification process less time-consuming.

"Abiotic" literally means without life. Abiotic plant disorders are nonbiological factors, usually associated with the plant's environment, that affect plants adversely. These environmental factors include temperature, moisture, soil $\mathrm{pH}$, air quality, light regime, and nutrition. If one or more of these factors goes above or below the optimum range for a given plant species, plant growth might be abnormal or adversely affected. Abiotic disorders may also be caused by human activities, such as pesticide and fertilizer applications.

One important indicator of an abiotic cause for a plant health problem is the distribution of the damage within the environmental unit. Plants generally grow in distinct environmental units such as vegetable gardens. Environmental problems are much more likely to affect most plants in the environmental unit uniformly. Disease and insect problems, on the other hand, tend to occur in clumps or hot spots within the unit, especially early in outbreaks. For example, if frost injury occurs in a vegetable garden, all 12 tomato plants are likely to have blackened leaves. A fungal pathogen, in contrast, may produce similar dark discoloration, but only on one or two plants in the early stages of the epidemic.

Before describing symptoms of abiotic disorders, two terms should be defined. Tissue exhibiting chlorosis has lost chlorophyll (the green plant pigment) and turns various shades of yellow. Necrotic tissue is dead tissue, and leaf tissue with necrosis will turn brown or gray. 


\section{Temperature}

Many fruit, ornamental, and — to a lesser extent--vegetable plants grown in Florida are quite sensitive to cold weather. This is especially true of plants that are native to tropical areas, such as papaya, begonia, and many palm species. Therefore, it should come as no surprise that these plants are frequently injured by low temperatures. This damage may even occur above $32^{\circ} \mathrm{F}\left(0^{\circ} \mathrm{C}\right)$ on particularly cold-sensitive species. Freezing temperatures damage plants by inducing ice-crystal formation in or between cells. Cell membranes rupture on contact with the sharp edges of these crystals. As large numbers of adjacent cells die, the damage (necrosis) becomes visible to the naked eye. Hence, a primary symptom of frost or freeze injury is areas of necrotic tissue, especially at leaf tips and margins (Fig. 4).

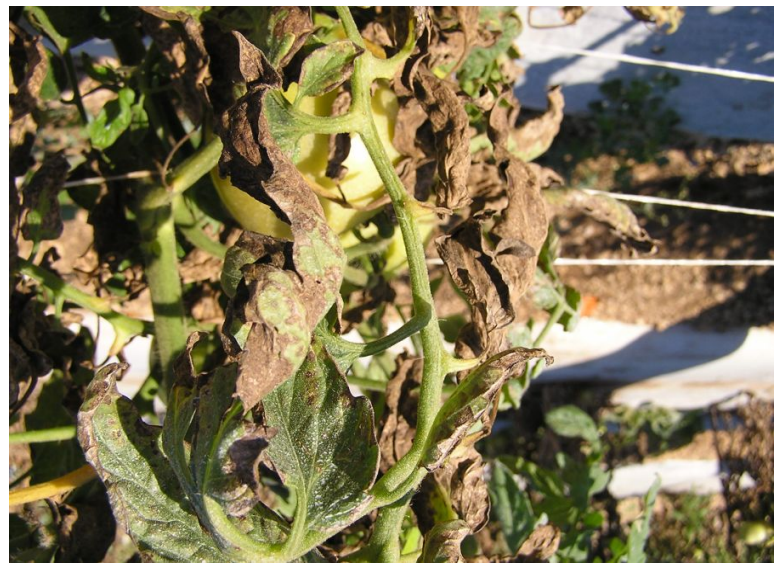

Figure 4. Freeze damaged tomato.

Excessively high temperatures cause plant proteins to become denatured and coagulate, making tissues dry out and die (Fig. 5). Whitish, papery appearing areas on leaves are often a symptom of heat damage.

\section{Moisture}

Moisture extremes may also adversely affect plants. Wilting results from insufficient plant water uptake because of either a plant disease or inadequate soil moisture. As a visual sign that wilting is a result of inadequate soil moisture, a cross-section of a wilted plant stem will show more or less healthy looking vascular tissue in light colors (off-white in herbaceous plants, light brown in woody plants). The stem tissue of plants wilted due to disease is usually

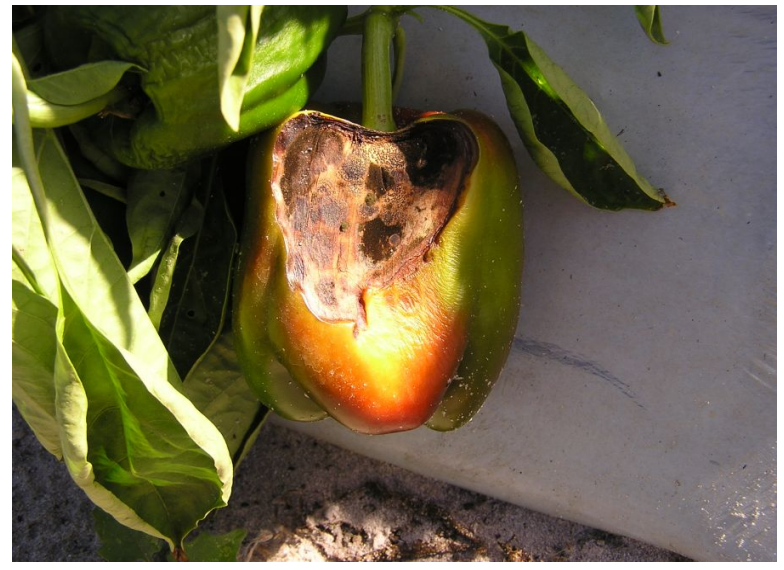

Figure 5. Sunscald damage to pepper fruit.

dark colored. Drought symptoms vary, depending on the plant species. Common symptoms include leaf tip and marginal necrosis (Fig. 6), or an overall dehydration that is usually indicated by a color change. For example, St. Augustine grass suffering from drought will turn blue-gray or green-gray, and the leaves will fold in half longitudinally.

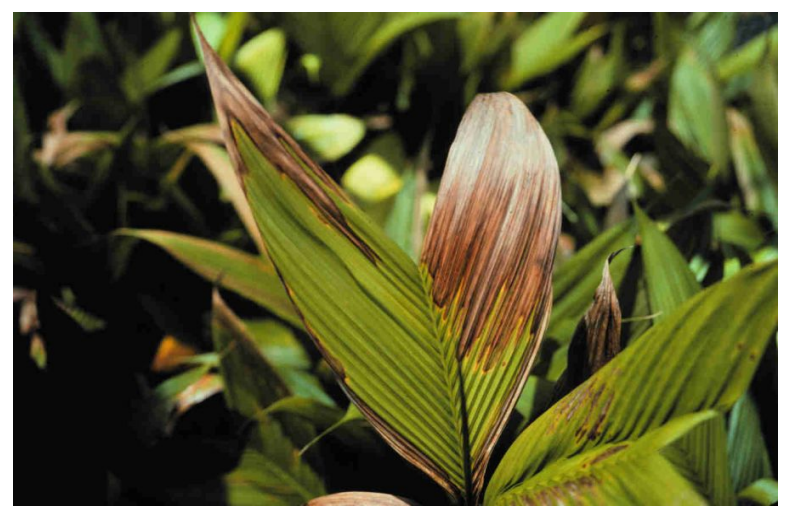

Figure 6. Drought stress on Geonoma.

Too much water, to the surprise of some gardeners and homeowners, may also be a problem. Oedema, which occurs most often on ornamental foliage plants with thick leaves, is a specific disorder caused by too much water (Fig. 7). Prolonged periods of overcast, rainy weather lead to reduced evaporation of water from plant containers and reduced natural water loss (transpiration) from leaves. However, if water uptake from the roots remains the same, plant leaf tissues can become engorged, leading to cell rupture, and producing brownish lesions that typically resemble leaf spots caused by living pathogens.

Plants that sit in water-logged soil long enough can actually wilt, will lack vigor, and develop light 


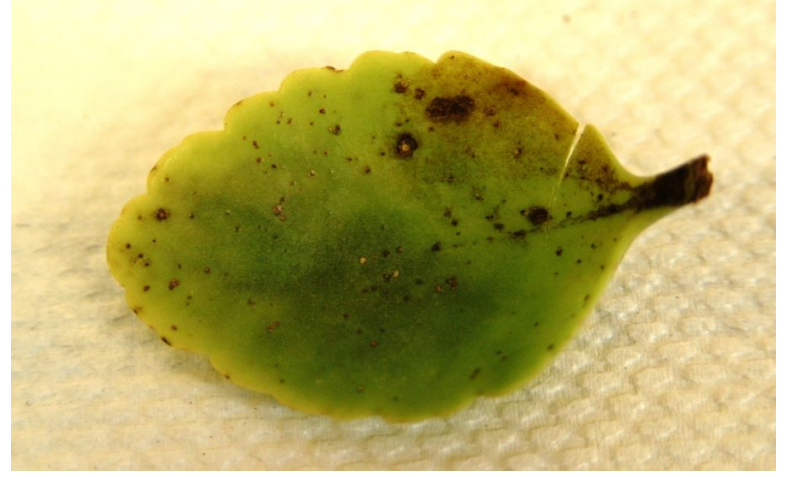

Figure 7. Oedema on kelanchoe.

green or pale yellow-green areas in leaves because of root oxygen deficiency (Fig. 8). Oxygen-starved roots do not function properly and are unable to withdraw water and nutrients from the soil. Of course, wet conditions also foster the development of root-rot fungal diseases, which will be described further in Guidelines for Identification and Management of Plant Disease Problems: Part II. Diagnosing Plant Diseases Caused by Fungi, Bacteria and Viruses (http://edis.ifas.ufl.edu/MG442).

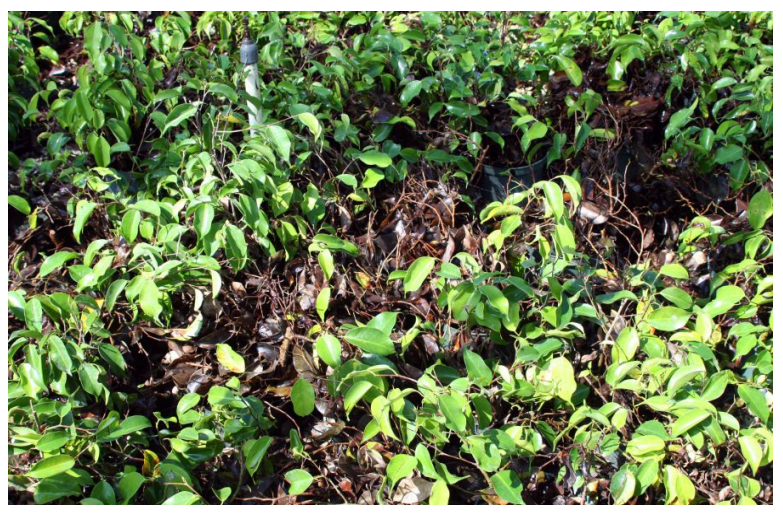

Figure 8. Excess water on ficus.

\section{Light}

Each plant species has a light preference-some plants thrive in shade while others require full sun for optimal growth. Sun-dependant plants grown in a low light regime produce less chlorophyll and develop a "leggy" or spindly appearance because the stem length between internodes becomes longer than normal. This is often a problem with house plants that do not receive enough light. Potted tomato plants grown in containers on patios that only receive direct sunlight for limited portions of the day during winter months may also show these symptoms. Not only will these plants appear thinner and taller than normal, but they will also droop considerably under the weight of a normal fruit load.

On the other hand, plants can also become "sunburned". If a plant is transplanted from a shady to a sunny location, the old leaves may develop large necrotic areas in the leaf center from the sudden sun exposure (Fig. 9). Leaves that develop after transplanting will be better adapted to the sun. Sunburn damage can often occur after a wind storm if the shade coverage is lost in the landscape. Keep in mind that some plants are not well adapted to full sun and will never look "normal" in sunny locations.

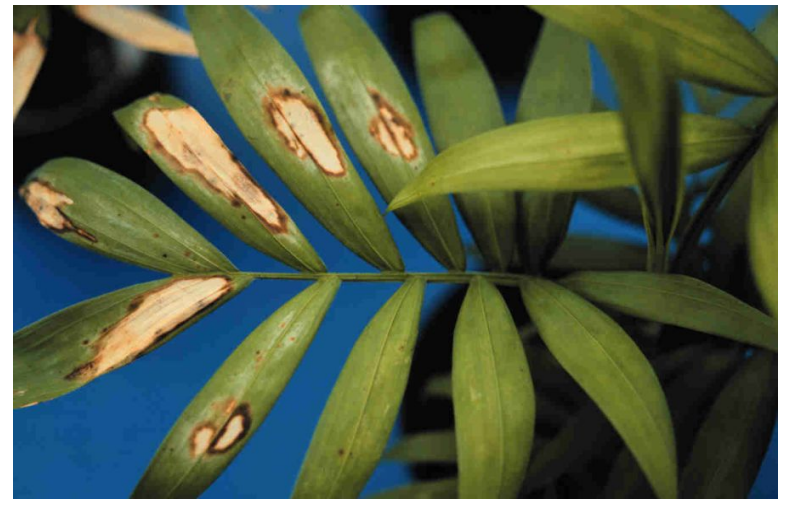

Figure 9. Sunburn on palm leaf.

\section{Nutrition}

Proper nutrition is important for plant growth. The major elements nitrogen $(\mathrm{N})$, phosphorus $(\mathrm{P})$, potassium $(\mathrm{K})$, and magnesium $(\mathrm{Mg})$ as well as a host of micronutrients, such as iron (Fe), manganese (Mn), zinc ( $\mathrm{Zn})$, and boron (B), must be supplied within a specific dosage range in order to avoid either deficiency or excess of any nutrient.

While each plant species has different nutrient requirements, the following is a list of the most common nutrient deficiencies, in order of relative importance, observed in Florida on general groups of plants grown in the landscape or gardens.

- Turf: nitrogen and iron.

- Palms: potassium, manganese, magnesium, boron, iron and nitrogen.

- Broadleaf plants (vegetables and ornamentals; herbaceous and woody): magnesium, iron, nitrogen, potassium, manganese, zinc, and boron. 
Phosphorus is rarely deficient in Florida landscapes, with the primary exception being the ornamental shrub ixora. Because container-grown plants are grown in potting mix rather than soil, they are more commonly deficient in nitrogen and iron.

Low $\mathrm{N}$ is usually associated with plants that are uniformly lighter green than normal, especially on older leaves. Broadleaf plants suffering from low $\mathrm{K}$ levels typically show interveinal (between the veins) yellowing or necrosis of the oldest leaves. Palms are especially susceptible to K deficiency, but the symptoms are different. The oldest leaves usually exhibit translucent orange, yellow or necrotic spots (Fig. 10). Mg deficiency is usually seen as an interveinal or marginal yellowing of the oldest leaves, with the remaining portion of the leaf remaining distinctly green.

$\mathrm{Zn}, \mathrm{Fe}, \mathrm{Mn}$, and copper $(\mathrm{Cu})$ often form insoluble salts in the soil. Under neutral to alkaline conditions ( $\mathrm{pH} 7.0$ or above), these metals are "tied up" and cannot be absorbed by roots, which results in striking deficiency symptoms. These deficiencies are usually seen as yellowing of the newest leaves. Mn deficiency is also characterized by necrotic spotting, streaking or blotches. Usually the yellowing or necrosis is interveinal, with leaf veins remaining conspicuously green (Fig. 11). Fe deficiency can also be seen as an overall yellowing of the plant which is more severe on the newest growth (the opposite of $\mathrm{N}$ deficiency). Deficiency of boron (B) manifests as tiny, distorted growth of young leaves, upward cupping of leaves, and a "witches broom" effect (multiple, tiny branches at shoot tips).

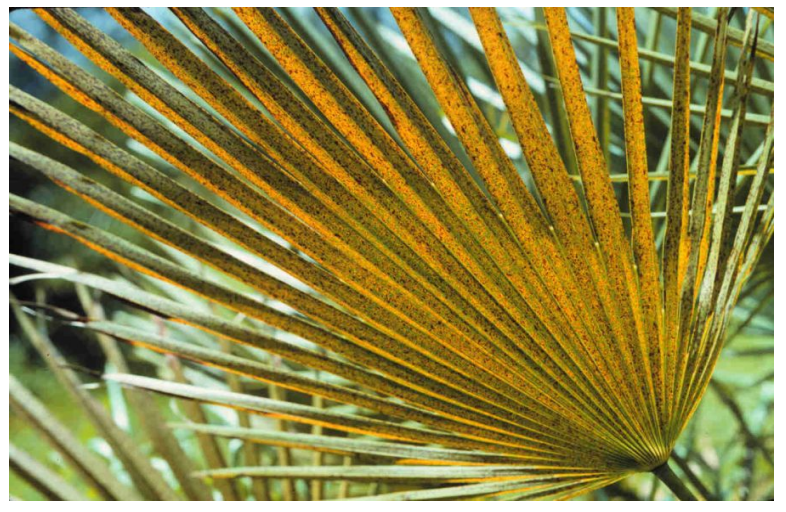

Figure 10. Potassium (K) deficiency on Chamaerops humilus.

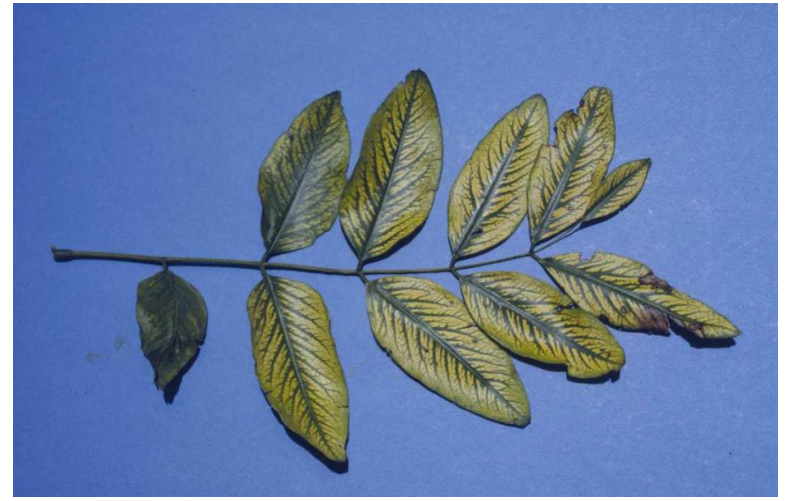

Figure 11. Manganese (Mn) deficiency on Cassia fistula.

Excess minerals may also injure plants. Toxicity from excess $\mathrm{Cu}$ and $\mathrm{B}$ are particularly noteworthy. Excess $\mathrm{Cu}$ or B fertilizer sprays may result in necrotic leaf spots on leaves that can easily be confused with fungal leaf spots or contact pesticide damage. In these cases, damage is greatest where droplets of the fertilizer spray accumulate, such as leaf tips. If excessive B fertilizer has been applied to the soil, B toxicity symptoms include marginal or tip necrosis on the oldest leaves.

It is also important to note that plants can suffer from soluble salt injury when rates of water-soluble fertilizers are too high. High soluble salt concentrations in the root zone can burn roots. In these cases, young plants may wilt, suggesting damping-off problems caused by fungi (see Part II: Diagnosing Plant Diseases Caused by Fungi, Bacteria and Viruses at http://edis.ifas.ufl.edu/MG442). More mature plants may exhibit leaf tip and marginal necrosis burn (symptoms similar to drought), wilting, or even Fe deficiency symptoms.

\section{Pesticide Phytotoxicity}

Another type of plant health problem that you may observe is phytotoxicity from pesticides. The pesticides may have been sprayed directly on plants, applied as granules around the base of the plant or to the lawn, or may have drifted over from applications to nearby plants. This type of phytotoxicity may very well be confused with viral diseases or abiotic disorders.

Growth-regulator-type injury can occur on broad-leaved plants from absorption of certain herbicides such as 2,4-D and dicamba. Affected plants become dramatically twisted with marked leaf 
distortion and a "shoestring" appearance of leaves (Fig. 12).

A great range of symptoms are associated with injury from other pesticides. These include bleached (white) spots, marginal yellowing and browning (necrosis) of leaves, stunted growth, stem and branch dieback, and interveinal or veinal yellowing (Figs. 13 and 14). Each pesticide and host interaction is unique, but, in general, contact and systemic pesticides applied as foliar sprays result in localized yellow or necrotic "spots" wherever the spray has landed on the plant, although damage is usually greatest where droplets accumulate, such as leaf tips. Systemic pesticides applied to the soil (granules, drenches, etc.) affect new growth.

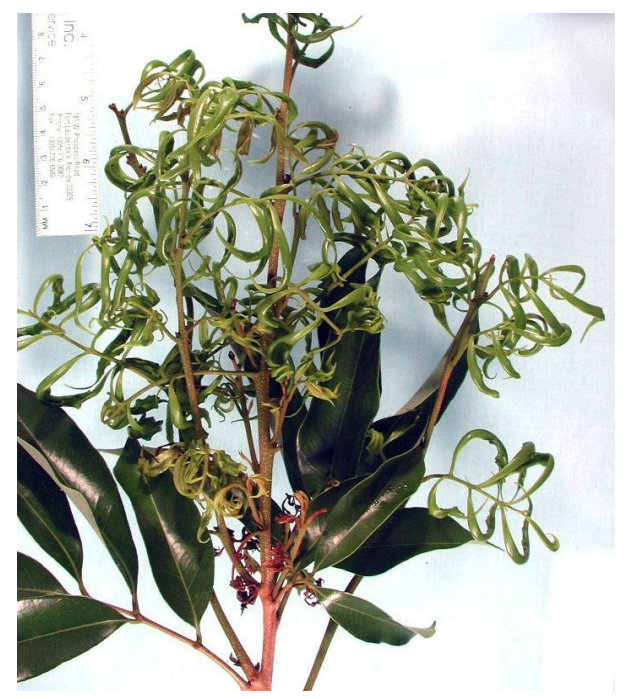

Figure 12. 2,4-D herbicide damage to litchi.

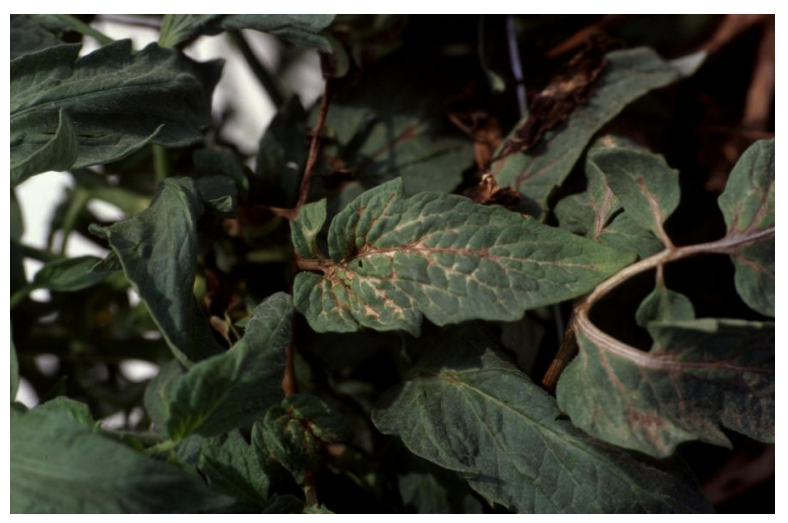

Figure 13. Metribuzin herbicide injury to tomato leaves.

It is important that Master Gardeners inquire into pesticide use over the past three months on both injured plants and other plants in their proximity. It

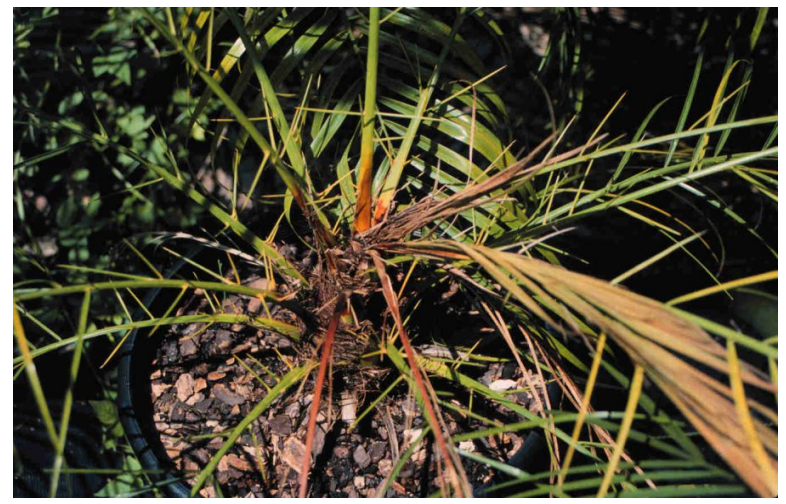

Figure 14. Snapshop herbicide damage to palm.

may be particularly important to note the client's use of professional lawn maintenance companies.

\section{Conclusion}

Now that we have examined insect injury and abiotic causes of plant damage, we will explore the traditional world of plant pathology in Part II-the study of plant health problems caused by microorganisms (http://edis.ifas.ufl.edu/MG442). 